\title{
Recruitment failure and shifts in community structure following mass mortality limit recovery prospects of black abalone
}

\author{
C. Melissa Miner ${ }^{1, *}$, Jessica M. Altstatt ${ }^{2}$, Peter T. Raimondi ${ }^{3}$, Todd E. Minchinton ${ }^{3,4}$ \\ ${ }^{1}$ Institute of Marine Science, University of California, Center for Ocean Health, Long Marine Laboratory, 100 Shaffer Road, \\ Santa Cruz, California 95060-5730, USA \\ ${ }^{2}$ Santa Barbara Channelkeeper, 714 Bond Street, Santa Barbara, California 93103, USA \\ ${ }^{3}$ Department of Ecology and Evolutionary Biology, University of California, Center for Ocean Health, Long Marine Lab, \\ 100 Shaffer Road, Santa Cruz, California 95060, USA \\ ${ }^{4}$ Present address: Institute for Conservation Biology and School of Biological Sciences, University of Wollongong, \\ New South Wales 2522, Australia
}

\begin{abstract}
Mass mortalities of species can fundamentally alter the structure of natural communities, which can in turn negatively impact species' recovery. Beginning in 1994, some of the largest remaining populations of black abalone Haliotis cracherodii on the mainland coast of California, experienced mass mortalities due to the fatal disease called 'withering syndrome', which led to its listing as a species of concern by the USA National Marine Fisheries Service. We have been monitoring black abalone populations along the coast of southern and central California since 1992, and detection of withering syndrome at our southernmost site prompted us to investigate how the impending decline of this dominant grazer might correlate with changes in black abalone recruitment and the rocky intertidal community in which it lives. Quantitative surveys before and after mass mortalities revealed that, after black abalone declined, there was a shift in the composition of the intertidal species assemblage from one dominated by bare rock and crustose coralline algae (good quality abalone habitat) to one with increased cover of sessile invertebrates and sea urchins. Declines in abalone abundance were also correlated with a lack of recruitment to areas affected by withering syndrome, despite the presence of healthy adult populations only tens of kilometers away. This suggests that abalone recruitment might be limited by dispersal, a lack of quality habitat for settlement and early survival, or the continued presence of the disease agent. Recruitment failure and these dramatic shifts in habitat quality indicate that the outlook for recovery of black abalone is poor.
\end{abstract}

KEY WORDS: Withering syndrome $\cdot$ Haliotis cracherodii $\cdot$ Community structure $\cdot$ Recruitment limitation $\cdot$ Marine diseases $\cdot$ Mass mortality $\cdot$ Recovery $\cdot$ Rocky intertidal shores

\section{INTRODUCTION}

Massive declines of dominant species in ecological communities can fundamentally alter the structure and composition of these natural assemblages. Disease and over-harvesting are 2 increasingly important factors responsible for mass mortalities of marine species across the globe (Harvell et al. 1999, Jackson et al. 2001, Harvell et al. 2002). Predicting the recovery of marine species following mass mortalities is difficult, however, because the majority of taxa have planktonic propagules that may disperse great distances away from their local population of reproductive adults (Kinlan \& Gaines 2003). Recovery is therefore contingent upon successful recruitment of larvae into areas where local populations have been impacted. However, recruitment can be highly variable in space and time (e.g. Minchinton \& Scheibling 1991), and requires a convergence of favorable conditions, including an available supply of larvae and specific conditions in 
the benthic habitat conducive to larval settlement and early survival (e.g. Raimondi 1990, Minchinton \& Scheibling 1993).

Ironically, successful recruitment into areas impacted by mass mortality events is often dependent on the presence of healthy, conspecific adults. First, adults may be necessary to ensure a local supply of larvae if dispersal is limited by geographic or hydrological barriers (e.g. headlands, ocean currents) or a species' ability to disperse. Second, adults often attract larvae to an area simply by their presence or the release of chemical cues that induce settlement (e.g. Burke 1983, Raimondi 1990, Minchinton 1997). Finally, adults may maintain suitable habitat for larval settlement and juvenile survival (Douros 1985). Consequently, when adults decline in an area, there may no longer be an adequate supply of larvae, suitable cues for settlement, or quality habitat for juvenile survival, which together may limit recruitment necessary to ensure natural recovery of impacted populations.

The once abundant black abalone Haliotis cracherodii has virtually disappeared from rocky intertidal shores of southern California, USA. Declines are due primarily to a fatal disease called 'withering syndrome' (Lafferty \& Kuris 1993, Altstatt et al. 1996, Raimondi et al. 2002). Withering syndrome is caused by the bacterium 'Candidatus Xenohaliotis californiensis', which attacks the lining of the digestive track and results in reduced body mass, weakness, and eventual withering of the abalone's foot until it can no longer cling to the substratum (Friedman et al. 2000). Declines have been so severe across all regions of southern California that the USA National Marine Fisheries Service now lists Haliotis cracherodii as a species of concern.

Black abalone are large, long-lived (>30 yr), locally abundant space occupiers on rocky intertidal reefs and may play a key role in maintaining favorable habitat for conspecific recruitment and determining community structure (Cox 1962, Blecha et al. 1992, Richards \& Davis 1993). Areas densely populated by black abalone are typically characterized by bare rock or crustose coralline algae (Douros 1985, authors' pers. obs.), and crustose coralline algae release a chemical cue that induces settlement and metamorphosis in several species of abalone larvae (Morse et al. 1979, Shepherd \& Turner 1985, McShane 1992), although this has not yet been tested directly for Haliotis cracheroidii. Other investigators have observed a substantial reduction or complete absence of abalone recruitment following mass mortality of black abalone due to withering syndrome (Richards \& Davis 1993, Tissot 1995). Adult abalone are primarily drift feeders, but they may maintain suitable conditions for recruitment of conspecifics by preventing colonization of other invertebrates and algae by pre-empting space on the substra- tum and dislodging newly settled larvae or algal spores through their movements and grazing (Leighton \& Boolootian 1963). Indeed, researchers monitoring black abalone on the Channel Islands in California, USA, noted increased cover of encrusting sessile invertebrates following the decline of black abalone (Richards \& Davis 1993). Although these observations were correlative, they suggest that the activities of adult abalone may ensure the availability of a suitable habitat for settlement, and thus facilitate local recruitment and recovery of conspecific populations.

In addition to these shifts in habitat structure due to the decline of adults, recruitment of black abalone may be further retarded by the decreased numbers of adults in the local population. Abalone are dioecious broadcast spawners and are thought to require densely aggregated adults to ensure fertilization success (Prince et al. 1987, Miller \& Lawrenz-Miller 1993). If densities drop below a critical level, the probability of successful fertilization is low because the distance between individuals increases. The need for local fertilization is critical because there is evidence that black abalone larvae have limited dispersal, localized recruitment and relatively closed populations (Prince et al. 1988, Hamm \& Burton 2000, Chambers et al. 2006). Consequently, black abalone recruitment and recovery is likely to be a positive function of the local abundance of adults (McShane 1992, Raimondi et al. 2002).

We hypothesize that recovery of black abalone populations will be hindered in areas where massive declines have occurred due to limitations placed on recruitment, particularly a lack of larval supply and shifts in community structure unfavorable to larval settlement and early survival. No study, however, has investigated long-term changes in community structure and patterns of abalone recruitment following mass mortalities of black abalone due to withering syndrome. Here we present quantitative data from 2 longterm monitoring studies that extend from before to after the mass mortalities of black abalone. In the first study, we quantified how the structure and composition of species assemblages in intertidal crevice habitats changed over a 6 yr period at 3 sites before and after abalone declines due to withering syndrome. In the second study, we quantified how recruitment of abalone varies with adult abundance over a $13 \mathrm{yr}$ period at 8 sites impacted and 4 sites not impacted by withering syndrome.

\section{MATERIALS AND METHODS}

Shifts in community structure. Changes to intertidal community structure coincident with black abalone 
decline due to withering syndrome were monitored for 6 yr (1996 to 2002) at 3 sites (Boat House, Stairs, and Purisima Point) along the coast of southern California (Fig. 1). Sampling was done on 3 dates: January 1996, the initial sampling time; June 1998, when all 3 sites had been severely impacted by withering syndrome; and January 2002, the final sampling date. Boat House and Stairs are gently sloping rocky platforms with crevices, whereas Purisima Point is a long, jutting boulder field interspersed by sections of rocky reef with crevices. Crevices at Boat House and Purisima Point are wide and open, whereas those at Stairs are narrower and abalone were on average slightly smaller there, probably due to the restricted crevice size. At all sites, black abalone were found almost exclusively lining the tops and bottoms of rock crevices in the low to mid intertidal zone and, therefore, sampling of community structure (and recruitment, see below) was restricted to these crevice habitats.

At each site we selected 10 crevices, each approximately $2 \mathrm{~m}$ long and of variable depth (ranging from 10 to $75 \mathrm{~cm}$ deep), in which to sample community structure over time. Crevices within a site were selected for similar shape, exposure to waves and sun, and black abalone density. Abalone in 5 of the 10 crevices were not manipulated, whereas abalone were added to the other 5 crevices as part of another experiment to control abalone densities in the face of declines due to withering syndrome. Our attempt to maintain abalone numbers failed and was discontinued after $2.5 \mathrm{yr}$. There was no significant difference in abalone number between crevices where abalone had been added and those where they had not, as determined by repeated measures analysis where the main effect and all interactions involving treatment were not significant (for each effect $p>0.6$, see densities in Table 1). Thus, we treated all 10 crevices as 'unmanipulated' replicates. Several crevices at Boat House and Stairs were destroyed or filled by sediment and shell grit during the 1997/98 El Niño storms and, consequently, fewer crevices (but at least $\mathrm{n}=7$ crevices per site) were sam- pled at these sites in June 1998 and January 2002 than in January 1996.

At each sampling time, all black abalone within each crevice were counted and measured. Densities of abalone at each site were calculated by dividing the sum of the number of abalone in all crevices by the area of available crevice habitat in which abalone could potentially live, and density is expressed as ind. $\mathrm{m}^{-2}$. Individuals $>40 \mathrm{~mm}$ in length (maximal shell length) were measured to the nearest $10 \mathrm{~mm}$ and those $\leq 40 \mathrm{~mm}$ to the nearest $5 \mathrm{~mm}$. Adult abalone were classified as individuals $\geq 50 \mathrm{~mm}$ and juvenile recruits as individuals $<50 \mathrm{~mm}$, which is consistent with Leighton and Boolootian (1963) in that individuals $\geq 45 \mathrm{~mm}$ were considered to be adults and juveniles were $<45 \mathrm{~mm}$ in length.

In each crevice, we also quantified the percent cover of species occupying the rock surface using a point intercept method. Permanent bolts were installed to delineate the ends of each crevice and a transect tape was then run parallel to the crevice opening and between the 2 bolts. Only the tops of crevices were sampled because the bottoms were occasionally covered with sand and shell grit, making sampling difficult. Percent cover was estimated by placing a rod (with points marked every 3 or $6 \mathrm{~cm}$ along its length, depending on crevice depth) perpendicular to and at evenly spaced intervals along the transect tape. The species occurring directly beneath each marked point on the rod was recorded. The interval at which the rod was placed along each transect was also adjusted depending on crevice length in order to sample a similar number of points within each crevice (approximately 100 points).

Species were lumped into relatively broad categories because we were mainly interested in general changes in community structure (e.g. did free space get replaced by encrusting invertebrates?) and, moreover, species identification was often difficult within crevices. Cover categories included: non-coralline algal crusts, coralline algal crusts, articulated coralline

Table 1. Haliotis cracherodii. Mean $\left( \pm \mathrm{SE}\right.$ ) densities (ind. $\mathrm{m}^{-2}$ ) in crevices used to determine change to community structure. Abalone were added to 'addition' crevices only after withering syndrome caused populations to decline, in an attempt to maintain original densities

\begin{tabular}{|c|c|c|c|c|c|c|c|}
\hline \multirow[t]{2}{*}{ Site } & \multirow{2}{*}{ Treatment } & \multicolumn{2}{|c|}{ Jan/Feb 1996} & \multicolumn{2}{|c|}{ Jun 1998} & \multicolumn{2}{|c|}{ Jan 2002} \\
\hline & & Adults & Juveniles & Adults & Juveniles & Adults & Juveniles \\
\hline \multirow[t]{2}{*}{ Boat House } & Addition & $15.8 \pm 4.0$ & $1.4 \pm 0.5$ & $3.6 \pm 2.6$ & $1.0 \pm 1.0$ & $0.7 \pm 0.5$ & $0.3 \pm 0.3$ \\
\hline & Control & $11.0 \pm 2.4$ & $0.6 \pm 0.3$ & $4.3 \pm 2.3$ & 0 & $3.4 \pm 1.4$ & $0.7 \pm 0.3$ \\
\hline \multirow[t]{2}{*}{ Stairs } & Addition & $38.4 \pm 6.3$ & $5.8 \pm 3.3$ & $3.9 \pm 0.9$ & $0.7 \pm 0.7$ & $0.8 \pm 0.5$ & 0 \\
\hline & Control & $48.8 \pm 8.5$ & $12.9 \pm 3.9$ & $1.5 \pm 1.5$ & 0 & $1.1 \pm 0.6$ & 0 \\
\hline \multirow[t]{2}{*}{ Purisima } & Addition & $19.0 \pm 2.4$ & $0.4 \pm 0.4$ & $5.4 \pm 1.3$ & $0.9 \pm 0.4$ & 0 & $0.5 \pm 0.2$ \\
\hline & Control & $18.0 \pm 5.5$ & $0.6 \pm 0.5$ & $7.3 \pm 3.6$ & $0.1 \pm 0.1$ & $0.2 \pm 0.2$ & 0 \\
\hline
\end{tabular}


algae, other algae (all algae not included in previous algal groups, common spp. included Mastocarpus papillatus, Mazzaella flaccida, Endocladia muricata, Porphyra spp.), barnacles (Tetraclita rubescens, Balanus glandula, Chthamalus fissus/dalli), tube worms and tube snails (Phragmatopoma californica, Serpula vermicularis, Spirobranchus spinosus, Spirorbis spp., Salmacina tribranchiata, Serpulorbis squamigerus, Petalochonchus montereyensis), anemones (Anthoplueura elegantissima, A. xanthogrammica), sea ur-

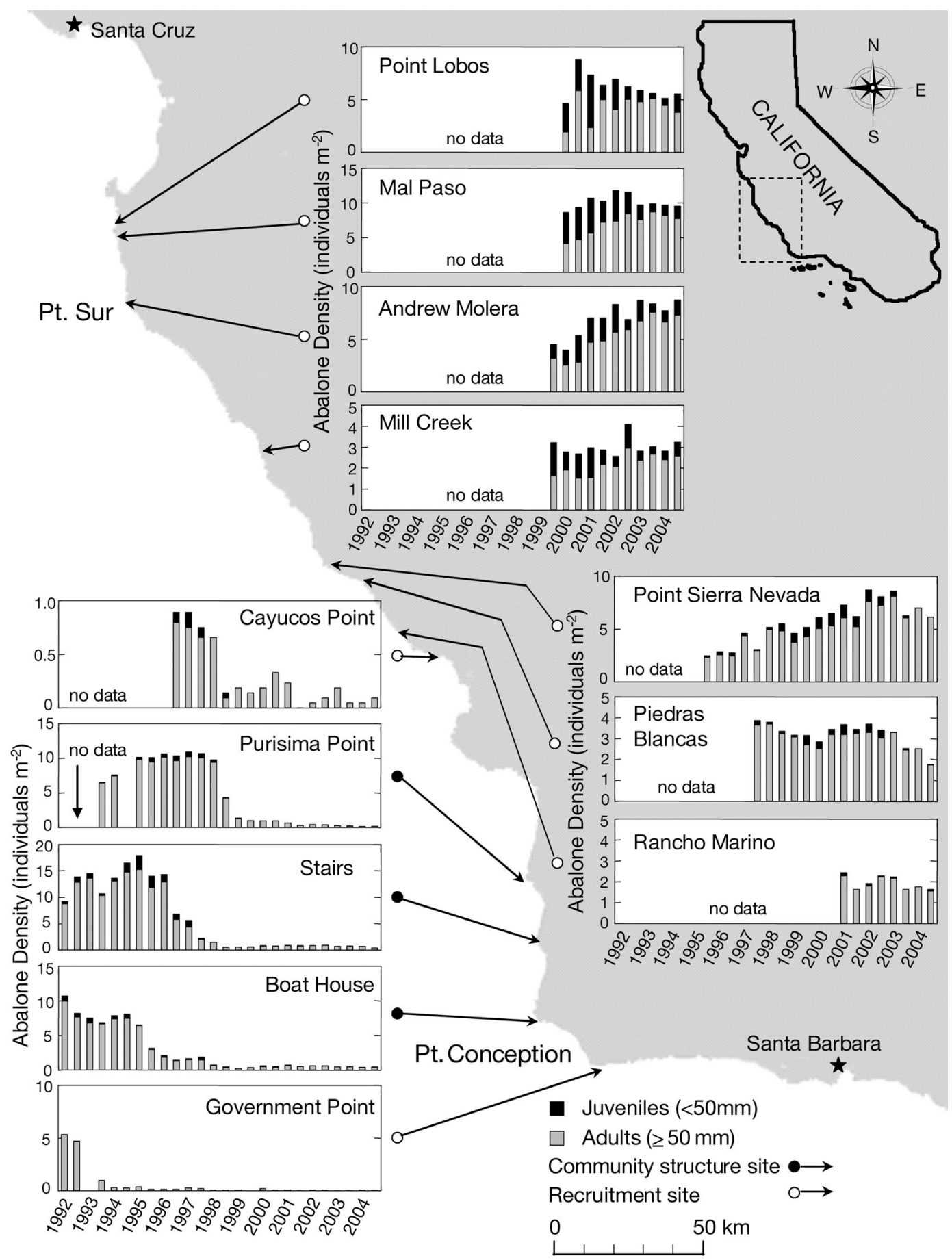

Fig. 1. Location of intertidal sites where community structure and recruitment were monitored, and densities of black abalone Haliotis cracherodii adults and juveniles at these sites over time. Note differences in scale on $y$-axes 
chins (mainly Strongylocentrotus purpuratus, rarely $S$. franciscanus), encrusting invertebrates (sponges, bryozoans, tunicates, hydroids), seastars (mainly Pisaster ochraceus and Asterina miniata), and bare rock. When a point fell on a black abalone, it was recorded as an abalone on top of whatever was the nearest species (or bare rock). For analysis, these points for this nearest species were lumped with their respective species category so that a decline in percent cover of abalone would not drive the patterns of change over time. For example, if a point was recorded as 'black abalone on bare rock' this point was lumped with the 'bare rock' category.

Temporal changes in community structure among sites were displayed using canonical discriminant analysis (CDA) and were tested for statistically using multivariate analysis of variance (MANOVA). We designated species categories (see above) as the dependent variables and site and time as the independent variables in the model. Percent cover data were examined for homogeneity of variances and normality using box plots and normal distribution probability plots. To meet these assumptions, data were square root transformed. In addition, we examined the equality of the group variance-covariance matrices by running a principal components analysis on the covariance matrix of the transformed data. Only variables in the CDA with loadings (correlations between each variable and the discriminant function) $\geq 0.3$, and standardized coefficients (contribution of each variable to a canonical axis) $\geq 0.3$ were used to interpret community change over time.

Recruitment of black abalone. In addition to documenting changes in community structure at Boat House, Stairs and Purisima Point, we quantified adult abundance and recruitment of abalone at these and 9 other sites over 5 to 13 yr (from spring 1992 to autumn 2004), 5 that had been impacted by withering syndrome (Government Point, Cayucos Point, Rancho Marino, Piedras Blancas, and Point Sierra Nevada) and 4 not impacted by the disease (Mill Creek, Andrew Molera, Mal Paso, and Point Lobos) (Fig. 1). Note that due to the northward progression of the disease, 'impacted' and 'non-impacted' sites are spatially separated. However, no formal statistics were performed on the data. Numbers and sizes of black abalone occurring within 3 large, permanent plots (plot areas ranged from 20 to $87 \mathrm{~m}^{2}$ ) at each of the 12 sites were recorded in the spring (usually February to March) and autumn (usually October to November) of each year. Abalone occurred almost exclusively in a few crevices within our much larger plots. Therefore, densities of abalone at each site were calculated by dividing the sum of the number of abalone in all 3 plots by the area of the available crevice habitat in which abalone could potentially live (which included areas with or without abalone), and density is expressed as ind. $\mathrm{m}^{-2}$. Adults and juvenile recruits were measured and classified based on their lengths as described in the previous subsection. Additional details of sampling methods have been previously described in Altstatt et al. (1996) and Raimondi et al. (2002).

Using the data from all 12 sites, we examined the form of the relationship (particularly whether it was positive) between the abundance of adults and recruitment at a site, and how this relationship varied according to whether samples had been collected at sites that had been impacted or not impacted by withering syndrome. 'Impacted' samples were those collected from sites following abalone decline due to the disease. 'Not impacted' samples were those collected from sites that had not been affected by withering syndrome at the time of sampling, including those samples taken from impacted sites prior to the appearance of the disease and abalone decline at that site. Samples collected from sites during periods when abalone were declining due to withering syndrome were excluded. Examination of the adult-recruit relationship was done by plotting the density of adults at a site in the autumn or spring of one year versus the density of juvenile recruits at the same site and time in the following year. The relationship was lagged by a year because reproduction by adults occurs from autumn to spring, with recruitment in the summer, and juveniles reach a size at which they can be counted by the following autumn to spring. Therefore, the abundance of juveniles sampled in autumn (or spring) in one year would reflect the abundance of reproductive adults from autumn (or spring) in the previous year. Note that our size cut-off for juvenile recruits $(<50 \mathrm{~mm})$ may lead to individuals being included in multiple samples since black abalone take approximately 2 yr to reach sizes $\geq 50 \mathrm{~mm}$ (Leighton \& Boolootian 1963). However, because we are simply showing the pattern of relationship between adults and juveniles, and not performing statistics on these data, this non-independence was not a concern.

\section{RESULTS}

\section{Shifts in community structure}

Black abalone numbers began to decline in crevices at Boat House just before the initiation of the study (Figs. 1 \& 2). A preliminary count was done in November 1995 when crevices were chosen, and numbers had declined sharply by January 1996, when treatments were initiated. A decline in abalone abundance at Stairs soon followed, beginning shortly 

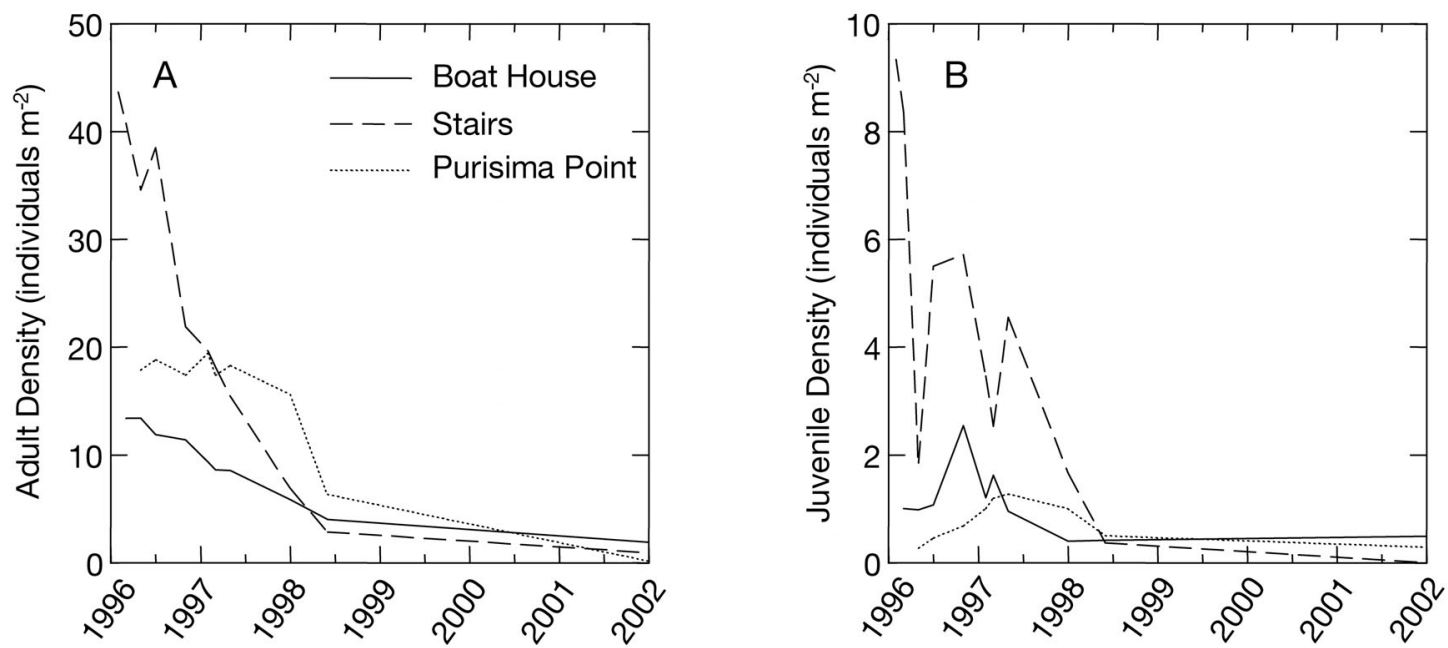

Fig. 2. Haliotis cracherodii. Mean density of (A) adults and (B) juveniles in crevices at Boat House, Stairs and Purisima Point, where community structure was monitored. Note differences in scale on $y$-axes

after the initial sample in January 1996 (Figs. 1 \& 2). The black abalone population at Purisima Point appeared to be healthy until just after January 1998 (Figs. 1 \& 2). At all sites, declines in abalone abundance were accompanied by observations in the field of individuals across all size classes with symptoms of withering syndrome. The onset of withering syndrome and timing of abalone decline in crevices used to monitor community structure at these sites was coincident with those observed in the permanent plots used to monitor recruitment at these sites since 1992 (compare Figs. 1 \& 2).

There were very high levels of discrimination in the structure of the crevice communities over time and space (MANOVA: Pillai's trace $=2.191$, approximate $F=2.297, \mathrm{df}=88,536, \mathrm{p}<0.001$ ) (Fig. 3). The change in community structure displayed similar temporal trajectories along the first discriminant axis, with the onset of change coincident with massive declines in abalone numbers (Figs. 2 \& 3). Changes were most extreme along the first discriminant axis for Boat House, which is likely due to abalone declining at this site first (Fig. 3). Community change along the second discriminant axis was similar at Boat House and Stairs, but not at Purisima.

Particular taxa explained a substantial part of the variation in the change in community structure associated with abalone decline among sites over time
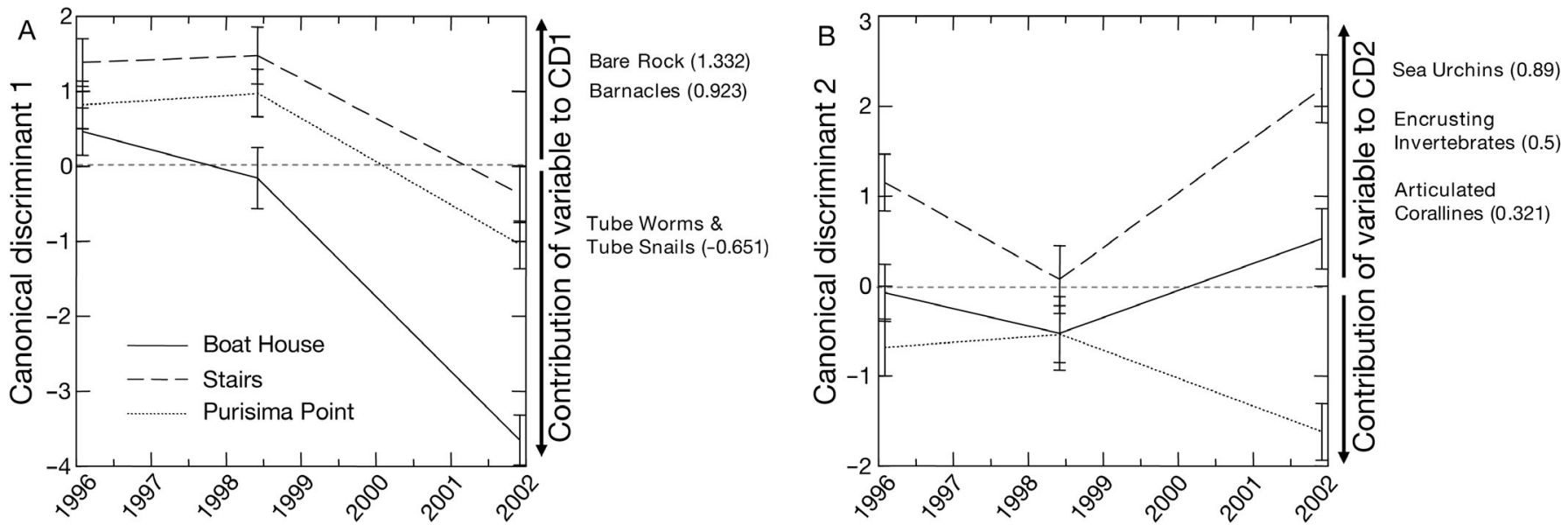

Fig. 3. Canonical discriminant analysis of species assemblages in crevices at Boat House, Stairs, and Purisima Point, showing changes in community structure over time. Relative contribution of each variable to each discriminant function (the standardized coefficient) is shown to the right of each graph. Only those variables with standardized coefficients and loadings $\geq 0.3$ were used for interpretation of community change. SE bars based on pooled SD across all samples. (A) CD1 explains $51.7 \%$ of total variation and (B) CD2 explains an additional $23.8 \%$ 
(Figs. 3 \& 4). Over time at all sites, the decline of black abalone was coincident with a decrease in the cover of bare rock and an increase in the cover of tube worms and tube snails (particularly at Boat House), as well as other encrusting invertebrates (Figs. 3 \& $4 A, B, D)$. Similar to bare rock, the overall cover of crustose coralline algae decreased over time (except in the narrow crevices at Stairs where urchins were particularly abundant), dramatically reducing the availability of free space on the substratum at Boat House and Purisima Point (Figs. 4E,F). Barnacle cover varied inconsistently among sites over time, particularly from January 1996 to June 1998, but there was an overall decline at Boat House and Stairs, while cover remained relatively constant at Purisima Point (Figs. $3 \& 4$ C). An increase in the number of sea urchins over time appears to be an important driver of community change at Boat House and Stairs as abalone decline, but not at Purisima Point (Figs. 3 \& $4 \mathrm{~F})$. Articulated coralline algae covered on average $<2 \%$ of the substratum, but great variability in their cover among sites over time help to discriminate the communities (Fig. 3B).

\section{Recruitment of black abalone}

Both before and after mass mortalities due to withering syndrome, the temporal patterns of abundance of juvenile recruits generally paralleled those of the adults at each site (Fig. 1). The abundance of both adult and juvenile abalone declined precipitously at the 5 southern sites impacted by withering syndrome (Government Point, Boat House, Stairs, Purisima Point and Cayucos Point), and abalone numbers in both size classes were beginning to decrease at the 3 sites more recently affected by the disease (Rancho Marino, Piedras Blancas and Point Sierra Nevada) (Fig. 1). By contrast, densities of adult abalone and juvenile recruits remained relatively constant at the 4 sites not yet affected by withering syndrome (Mill Creek, Andrew Molera, Mal Paso and Point Lobos). Note that recruitment was patchy in time at all unaffected sites, as well as at affected sites before being impacted by withering syndrome, indicating that fluctuations between periods of low and high recruitment is typical for healthy abalone populations (Fig. 1). Recruitment of juvenile abalone to sites
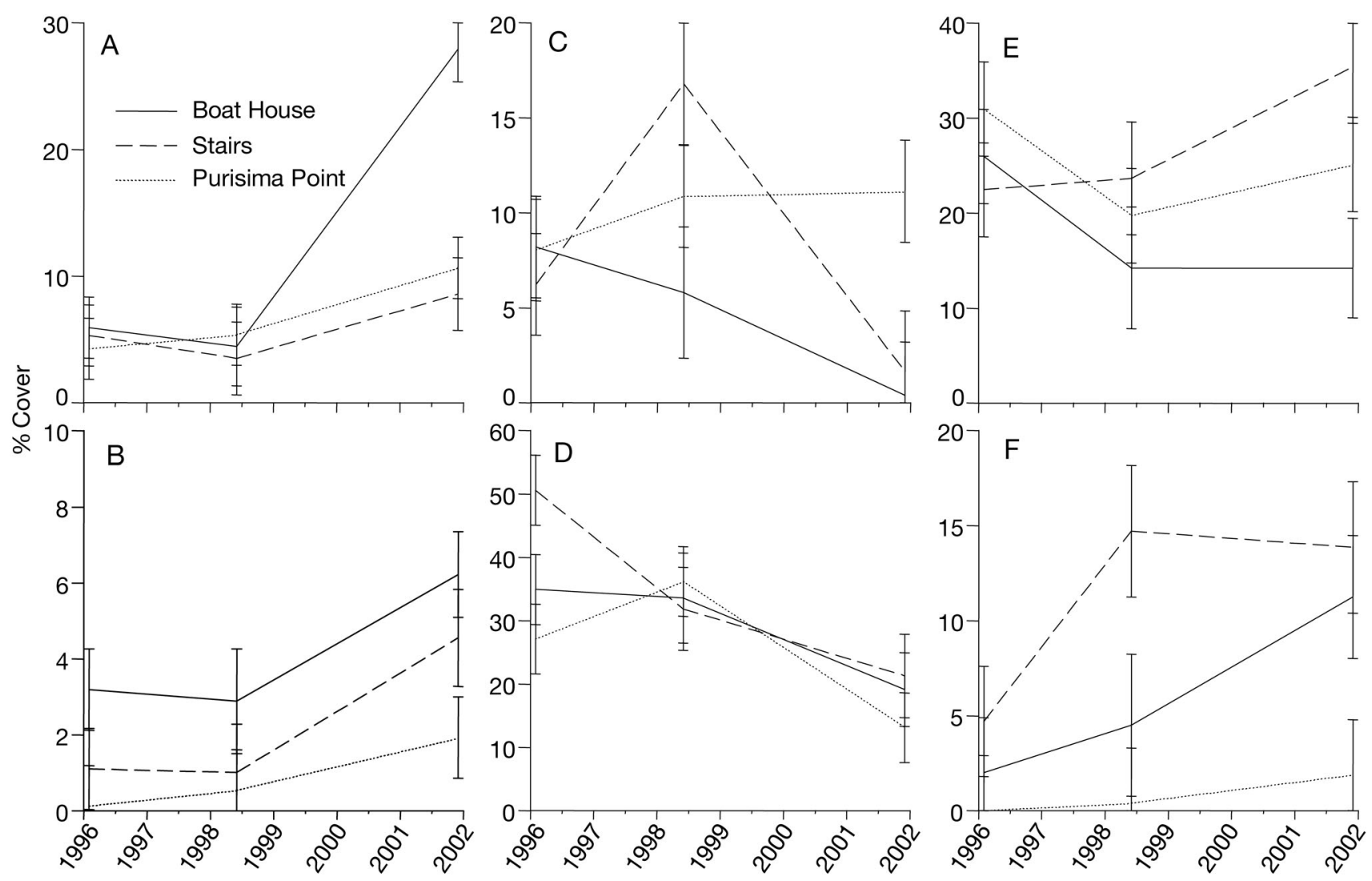

Fig. 4. Mean percent cover over time of (A) tubeworms and tube snails, (B) encrusting invertebrates (includes sponges, bryozoans, tunicates, and hydroids), (C) barnacles, (D) bare rock and (E) crustose coralline algae, and (F) mean number of urchins Strongylocentrotus purpuratus, in crevices at Boat House, Stairs and Purisima Point, where community structure was monitored. $\mathrm{SE}$ bars based on pooled SD across all samples. Note differences in scale on $y$-axes 
where there had been mass mortalities of adults was rare, despite successful recruitment at sites only tens of kilometers away (Fig. 1).

The relationship between the density of juvenile recruits and adult abalone was striking, with almost no recruitment of juveniles where adult density was $<1$ ind. $\mathrm{m}^{-2}$ (Fig. 5). Although most samples with adult densities $<1$ ind. $\mathrm{m}^{-2}$ occurred at sites that had been impacted by withering syndrome, this pattern also held for 2 non-impacted samples, suggesting that, even in the absence of the disease, recruitment occurs only when adult densities are $>1$ ind. $\mathrm{m}^{-2}$. Densities of juvenile recruits varied considerably at adult densities higher than this 'threshold', and did not appear to show any positive or negative trend. Because there was no apparent relationship (linear or otherwise) between adult densities and juvenile recruits other than this 'threshold' in adult density associated with recruitment, we did not perform any statistical analyses to test for a quantitative relationship.

\section{DISCUSSION}

The long-term and large-scale set of monitoring data presented here demonstrate an almost complete failure of recruitment to black abalone populations following mass mortalities due to withering syndrome. While this pattern has not been experimentally tested, the pattern of abalone declines from south to north, the close spacing of sites along the coast, and the lack of

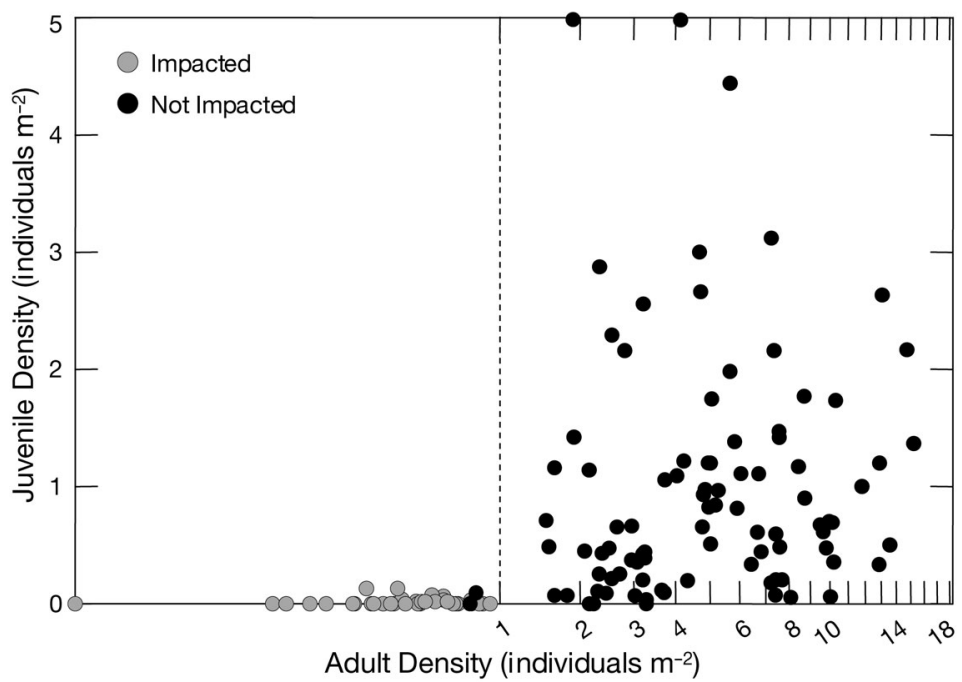

Fig. 5. Haliotis cracherodii. Relationship (lagged by 1 yr) between density of adults and juvenile recruits, for sites impacted or not impacted by withering syndrome (see 'Materials and methods' for details). To present clearly the range of adult densities at which recruitment occurred, the $x$ axis has been fourth-root transformed and a dashed line placed on graph at 1 ind. $\mathrm{m}^{-2}$ recruits following adult mortalities provide some of the best evidence to date suggesting that black abalone, like other abalone species, may have localized dispersal and relatively closed populations. Abalone decline has been followed by unfavorable shifts in the species assemblages occupying the crevices that provide important habitat for abalone recruitment and survival. Together, such changes may severely limit the ability of this threatened species to recover naturally from this serious disease.

Several explanations can be put forth to account for the lack of local recruitment to sites experiencing mass mortalities of black abalone including: (1) there is no local production of abalone larvae at these sites and, due to localized dispersal, larvae produced at nearby sites do not reach these sites, (2) abalone larvae disperse to sites but changes to the assemblage of species following abalone mortality do not provide suitable cues or habitats for successful settlement and early survival of larvae, and (3) abalone larvae disperse and recruit to sites but persistence of the disease at these sites results in their early mortality before they are large enough to be observed. While the data from our study cannot distinguish among these alternatives, evidence suggests that some are more plausible than others and highlights important directions for research.

Results here suggest that a lack of local larval production and dispersal limitation due to extremely localized dispersal of black abalone larvae may be the most plausible explanation for the lack of abalone recruitment to sites impacted by withering syndrome. First, the density and dispersion of adult black abalone at sites following disease was likely below that which is needed to ensure successful fertilization and, hence, a local supply of larvae. Abalone are dioecious broadcast spawners and require close proximity to other individuals for fertilization to occur (Prince et al. 1988, Miller \& Lawrenz-Miller 1993). Consequently, if the density of black abalone drops below the level required for successful fertilization (or if abalone are not suitably aggregated), then a local supply of larvae may no longer be available to replenish local populations. Other researchers have observed a similar cessation of black abalone recruitment after local populations dropped below some critical level (Miller \& LawrenzMiller 1993, Richards \& Davis 1993). Second, despite an abundance of reproductive adults at nearby northern sites, recruitment of juvenile abalone was rare at any site where abalone populations had been impacted by withering syndrome. For example, no recruits were observed at Government Point after 
mass mortalities, despite the dense and healthy populations of adults at Boat House, Stairs, and Purisima Point only 15 to $30 \mathrm{~km}$ away. Evidence that black abalone populations are relatively closed is further supported by genetic data (Hamm \& Burton 2000), which demonstrated localized population differentiation of black abalone, and the local retention of larvae has been shown to exist for another species of abalone (Prince et al. 1988).

It is also possible that abalone larvae arrive at sites impacted by the disease but that the species assemblages of the crevice communities have changed, potentially in a direction that is not suitable for the recruitment of this once-dominant grazer. On average for all sites where we monitored community structure, mass mortalities of black abalone were followed by declines in the cover of bare rock and crustose coralline algae and increases in the cover of sessile invertebrates. Because we did not directly manipulate abalone abundance, we cannot rule out alternative explanations for the observed changes in community structure, such as physiological responses of organisms to climate change, or changes in the physical characteristics of the sites (e.g. sedimentation, water quality). Nevertheless, the expectation is that these large-scale phenomena would lead to broad-scale changes to benthic assemblages and habitat across entire sites throughout the region. We have $15 \mathrm{yr}$ of monitoring data for a variety of species spread throughout each of the sites where crevice communities were studied, and have not observed similar changes in areas outside of the crevices (Miner et al. 2005). Further support comes from Douros (1985), who found that the density of black abalone in intertidal areas was positively correlated with the cover of crustose coralline algae and negatively correlated with the cover of tube worms and fleshy algae. Free space on the substratum is necessary for abalone settlement, and crustose coralline algae (and their associated chemicals and biofilms) are known to induce settlement of abalone larvae (Morse et al. 1979, Douros 1985, Day \& Branch 2002a). The presence of conspecific individuals, particularly adults, may also be important for settlement as their grazing activities might maintain the cover of crustose coralline algae (Douros 1985) and their mucus on the substratum may act as a positive settlement cue for abalone larvae (Bryan \& Qian 1998), but Naylor \& McShane (2001) have reported that adult abalone can smother conspecific recruits. The increased cover of tube worms and tube snails documented in this study may be particularly detrimental to recolonization because tube worms have been shown to prey on abalone larvae (Naylor \& McShane 1997). Increases in the colonial tube worm Phragmatopoma californica may have an additional impact by filling in crevices and cementing together spaces between boulders, which are important microhabitats for abalone recruitment (Douros 1985, Shepherd \& Turner 1985, Miller \& Lawrenz-Miller 1993).

Shifts in the species assemblages from what might be considered favorable to unfavorable habitat for settlement by abalone was not equivalent across sites. In particular, changes in community structure at Stairs were largely driven by an increase in the number of urchins, which may compete with abalone for resources (Davis et al. 1992, Day \& Fleming 1992), but may also maintain appropriate habitat for abalone recruitment through grazing of foliose algae and increasing the cover of crustose coralline algae (McShane 1992). Additionally, abalone recruits might benefit from the presence of sea urchins as a source of shelter from predation, as well as an enhanced food supply (Rogers-Bennett \& Pearse 1998, Day \& Branch 2002b, Day \& Branch 2002c, Tomascik \& Holmes 2003), although this relationship has not been demonstrated for Haliotis cracherodii and the relatively short-spined Strongylocentrotus pupuratus, which predominates in this intertidal region. Therefore, in the narrow crevices at Stairs it might be argued that habitat suitable for abalone recruitment persisted following the mass mortalities, yet there was still no abalone recruitment, supporting the contention that inadequate larval supply is limiting black abalone recovery.

It is also possible, however, that withering syndrome persists at sites long after it has devastated the local population so that black abalone recruits may not survive once they arrive, but this is a less likely explanation. Although there has been little research on the potential for withering syndrome to persist at lethal levels at a site after mass mortality, anecdotal evidence suggests that the amount of bacteria in the water column is reduced once black abalone populations have declined (C. Friedman pers. comm.). Therefore, it is unlikely that the absence of recruits is due to mortality by disease, particularly as some sites such as Government Point have had no recruits for many years. Nevertheless, it is not known whether the bacterium responsible for withering syndrome would multiply rapidly to lethal levels were there a sudden increase in black abalone numbers, such as would occur with an influx of recruits.

Finally, one could argue that abalone larvae are recruiting to areas in the intertidal zone outside of the crevice habitats studied here, and that we simply failed to observe them. For example, black abalone have been observed to recruit to coralline encrusted cobble beds (P. Raimondi pers. obs.). However, many of our sites with high abalone densities are located on rocky intertidal reefs that contain no cobble beds, and as demonstrated here, crevices are also important areas for black abalone recruitment. Thus, if recruitment 
was occurring at a site, at least some of the recruits should have been recorded. Moreover, given the spatial and temporal scope of the present study (and related monitoring programs sampling other species on these and other shores; see Miner et al. 2005), it is extremely unlikely that we would have failed to detect massive recruitment of black abalone. Ultimately, the rarity or absence of adults over more than a decade of sampling provides the best proof of recruitment failure following abalone decline. Therefore, the recruitment failure of black abalone may be attributable to a combination of the above explanations: an inadequate larval supply, shifts in community structure unsuitable for early settlement and survival, and the possible persistence of withering syndrome. Studies designed to differentiate among these alternatives should be focal areas of research to understand key limitations to the natural recovery or restoration efforts of this threatened species.

Thus far, management of black abalone populations has focused solely on their biology and has been geared towards successful spawning and rearing of black abalone larvae in the laboratory. The California Department of Fish and Game's Abalone Recovery and Management Plan (CDF \& G 2005) estimates that a minimum viable population size for all species of abalone, including black abalone, is 2000 ind. ha ${ }^{-1}$ $\left(0.2 \mathrm{~m}^{-2}\right)$ and that 6600 ind. ha ${ }^{-1}\left(0.66 \mathrm{~m}^{-2}\right)$ will sustain a fishery. These densities are far below the densities at which there was some natural recruitment in the present study (where significant recruitment was only detected at densities $>1$ ind. $\mathrm{m}^{-2}$ ); furthermore, these estimates were at sites not impacted by withering syndrome. Moreover, given the reproductive mode of abalone, which typically requires individuals in close proximity for successful fertilization, and the patchy nature of suitable abalone habitat in the intertidal area, management plans must consider not only the density of individuals at a local site at an appropriate spatial scale, but also the dispersion of larvae and the availability of suitable habitat. We advocate a shift to a whole-ecosystem based management approach and argue that knowledge about the entire intertidal species assemblage, the population dynamics of black abalone (including dispersion, density, recruitment trends, etc.), the habitat requirements for abalone settlement and the availability of such habitat, and the behavior of the withering syndrome pathogen would be critical for management-based recovery of the black abalone.

Acknowledgements. We thank L. MacDonald, G. Heistand, D. Hubbard, D. Farrar, and many others for their help in the field. The manuscript was much improved by comments from Mike Graham and 2 anonymous reviewers. We are grateful for funding from the Minerals Management Service, the Coastal Marine Institute at UC Santa Barbara, the County of Santa Barbara, and the Partnership for Interdisciplinary Studies of Coastal Oceans (PISCO): a long-term ecological consortium funded by the David and Lucille Packard Foundation and the Gordon and Betty Moore Foundation. T.E.M. was partially supported by a Natural Sciences and Engineering Research Council of Canada Postdoctoral Fellowship. We acknowledge N. Read and Vandenberg Air Force Base, B. Lundberg and the Cojo-Bixby Ranch, the Hearst Corporation, the Bureau of Land Management, the California State Park System, and the Kenneth S. Norris U.C. Reserve for access to sites. This is PISCO contribution number 217.

\section{LITERATURE CITED}

Altstatt JM, Ambrose RF, Engle JM, Haaker PL, Lafferty KD, Raimondi PT (1996) Recent declines of black abalone Haliotis cracherodii on the mainland coast of central California. Mar Ecol Prog Ser 142:185-192

Blecha JB, Steinbeck JR, Sommerville DC (1992) Aspects of the biology of the black abalone (Haliotis cracherodii) near Diablo Canyon, central California. In: Shepherd SA, Tegner MJ, Guzmán del Próo SA (eds) Abalone of the world: biology, fisheries, and culture. Proc 1st Int Symp Abalone. Blackwell Scientific Publications, Cambridge

Bryan PJ, Qian PY (1998) Induction of larval attachment and metamorphosis in the abalone Haliotis diversicolor (Reeve). J Exp Mar Biol Ecol 223:39-51

Burke RD (1983) The induction of metamorphosis of marine invertebrate larvae: stimulus and response. Can J Zool 61: $1701-1719$

CDF \& G (California Department of Fish \& Game) (2005) Abalone recovery and management plan. Resources Agency, Sacramento, CA. Available at: www.dfg.ca.gov/ mrd/armp/index.html

Chambers MD, VanBlaricom GR, Hauser L, Utter F, Friedman CS, (2006) Genetic structure of black abalone (Haliotis cracherodii) populations in the California islands and central California coast: impacts of larval dispersal and decimation from withering syndrome. J Exp Mar Biol Ecol 331: $173-185$

Cox KW (1962) California abalones, family Haliotidae. Calif Dep Fish Game Fish Bull 118:1-133

Davis GE, Richards DV, Haaker PL, Parker DO (1992) Abalone population declines and fishery management in southern California. In: Shepherd SA, Tegner MJ, Guzmán del Próo SA (eds) Abalone of the world: biology, fisheries, and culture. Proc 1st Int Symp Abalone. Blackwell Scientific Publications, Cambridge, p 237-249

Day E, Branch GM (2002a) Effects of benthic grazers on microalgal communities of morphologically different encrusting corallines: implications for abalone recruits. Mar Ecol Prog Ser 244:95-103

Day E, Branch GM (2002b) Effects of sea urchins (Parechinus angulosus) on recruits and juveniles of abalone (Haliotis midae). Ecol Monogr 72:133-149

Day EG, Branch GM (2002c) Influences of the sea urchin Parechinus angulosus (Leske) on the feeding behaviour and activity rhythms of juveniles of the South African abalone Haliotis midae Linn. J Exp Mar Biol Ecol 276:1-17

Day RW, Fleming AE (1992) The determinants and measurement of abalone growth. In: Shepherd SA, Tegner MJ, Guzmán del Próo SA (eds) Abalone of the world: biology, fisheries, and culture. Proc 1st Int Symp Abalone. Blackwell Scientific Publications, Cambridge, p 141-168 
Douros WJ (1985) Density, growth, reproduction and recruitment in an intertidal abalone: effects of intraspecific competition and prehistoric predation. MA, University of California Santa Barbara

Friedman CS, Andree KB, Beauchamp KA, Moore JD, Robbins TT, Shields JD, Hedrick RP (2000) 'Candidatus Xenohaliotis californiensis', a newly described pathogen of abalone, Haliotis spp., along the west coast of North America. Int J Syst Evol Microbiol 50:847-855

Hamm DE, Burton RS (2000) Population genetics of black abalone, Haliotis cracherodii, along the central California coast. J Exp Mar Biol Ecol 254:235-247

Harvell CD, Kim K, Burkholder JM, Colwell RR and 9 others (1999) Emerging marine diseases-climate links and anthropogenic factors. Science 285:1505-1510

Harvell CD, Mitchell CE, Ward JR, Altizer S, Dobson AP, Ostfeld RS, Samuel MD (2002) Climate warming and disease risks for terrestrial and marine biota. Science 296: 2158-2162

Jackson JBC, Kirby MX, Berger WH, Bjorndal KA and 15 others (2001) Historical overfishing and the recent collapse of coastal ecosystems. Science 293:629-638

Kinlan BP, Gaines SD (2003) Propagule dispersal in marine and terrestrial environments: a community perspective. Ecology 84:2007-2020

Lafferty KD, Kuris AM (1993) Mass mortality of abalone Haliotis cracherodii on the California Channel Islands: Tests of epidemiological hypotheses. Mar Ecol Prog Ser 96:239-248

Leighton D, Boolootian RA (1963) Diet and growth in the black abalone, Haliotis cracherodii. Ecology 44:227-238

McShane PE (1992) Early life history of abalone: a review. In: Shepherd SA, Tegner MJ, Guzmán del Próo SA (eds) Abalone of the world: biology, fisheries, and culture. Proc 1st Int Symp Abalone. Blackwell Scientific Publications, Cambridge, p 120-137

Miller AC, Lawrenz-Miller SE (1993) Long-term trends in black abalone, Haliotis cracherodii Leach, 1814, populations along the Palos Verdes peninsula, California. J Shellfish Res 12:195-200

Minchinton TE (1997) Life on the edge: conspecific attraction and recruitment of populations to disturbed habitats. Oecologia 111:45-52

Minchinton TE, Scheibling RE (1991) The influence of larval supply and settlement on the population-structure of barnacles. Ecology 72:1867-1879

Minchinton TE, Scheibling RE (1993) Free-space availability and larval substratum selection as determinants of barnacle population-structure in a developing rocky intertidal community. Mar Ecol Prog Ser 95:233-244

Editorial responsibility: Steven Morgan (Contributing Editor), Bodega Bay, California, USA
Miner CM, Raimondi PT, Ambrose RF, Engle JM, Murray SN (2005) Monitoring of rocky intertidal resources along the central and southern California mainland. Comprehensive report (1992-2003) for San Luis Obispo, Santa Barbara, Ventura, Los Angeles, and Orange Counties. Report No. MMS-2005-071. US Minerals Management Service, Pacific OCS Region

Morse DE, Hooker N, Duncan H, Jensen L (1979) Gammaaminobutyric acid, a neurotransmitter, induces planktonic abalone larvae to settle and begin metamorphosis. Science 204:407-410

Naylor JR, McShane PE (1997) Predation by polychaete worms on larval and post-settlement abalone Haliotis iris (Mollusca: Gastropoda). J Exp Mar Biol Ecol 214:283-290

Naylor JR, McShane PE (2001) Mortality of post-settlement abalone Haliotis iris caused by conspecific adults and wave exposure. N Z J Mar Freshw Res 35:363-369

Prince JD, Sellers TL, Ford WB, Talbot SR (1987) Experimental evidence for limited dispersal of haliotid larvae (genus Haliotis; Mollusca: Gastropoda). J Exp Mar Biol Ecol 106: 243-263

Prince JD, Sellers TL, Ford WB, Talbot SR (1988) Confirmation of a relationship between the localized abundance of breeding stock and recruitment for Haliotis rubra Leach (Mollusca: Gastropoda). J Exp Mar Biol Ecol 122:91-104

Raimondi PT (1990) Patterns, mechanisms, consequences of variability in settlement and recruitment of an intertidal barnacle. Ecol Monogr 60:283-309

Raimondi PT, Wilson CM, Ambrose RF, Engle JM, Minchinton TE (2002) Continued declines of black abalone along the coast of California: are mass mortalities related to El Niño events? Mar Ecol Prog Ser 242:143-152

Richards DV, Davis GE (1993) Early warnings of modern population collapse in black abalone Haliotis cracherodii, Leach, 1814 at the California Channel Islands. J Shellfish Res 12:189-194

Rogers-Bennett L, Pearse JS (1998) Experimental seeding of hatchery-reared juvenile red abalone in northern California. J Shellfish Res 17:877-880

Shepherd SA, Turner JA (1985) Studies on southern Australian abalone (genus Haliotis). VI. Habitat preference, abundance and predators of juveniles. J Exp Mar Biol Ecol 93:285-298

Tissot BN (1995) Recruitment, growth, and survivorship of black abalone on Santa Cruz Island following mass mortality. Bull S California Acad Sci 94:179-189

Tomascik T, Holmes H (2003) Distribution and abundance of Haliotis kamtschatkana in relation to habitat, competitors and predators in the Broken Group Islands, Pacific Rim National Park Reserve of Canada. J Shellfish Res 22:831-838

Submitted: October 28, 2005; Accepted: May 1, 2006

Proofs received from author(s): November 13, 2006 